\title{
Strategi Terhadap Pengembangan Kelembagaan BUMDESA di Kabupaten Jember
}

\author{
Herman Cahyo Diartho \\ Fakultas Ekonomi dan Bisnis, Universitas Jember \\ e-mail: hermancahyodiartho@yahoo.com
}

\begin{abstract}
ABSTRAK
Penelitian ini bertujuan untuk mengetahui kinerja kelembagaan BUMDESA di Kabupaten Jember. Penelitian ini menggunakan metode eksplanatori. Data dan informasi yang diperlukan terdiri atas data primer yaitu data yang diperoleh dari kuesioner atau wawancara dan data sekunder yaitu data pendukung yang diperoleh dari instansi terkait. Unit analisisnya adalah Kelembagaan BUMDesa di Kabupaten Jember. Hasil penelitian ini menunjukkan bahwa (1). Tata kelola kelembagaan merupakan faktor kunci penentu keberhasilan usaha dari setiap jenis BUMDesa. Hal ini disebabkan karena setiap jenis usaha BUMDesa tidak berdiri sendiri tetapi memiliki kaitan mata rantai dengan faktor lain yang sangat mempengaruhi keberlanjutan usaha. Keterkaitan ini bagaikan sebuah mata rantai dan apabila rantai ini putus maka usaha yang dilakukan oleh BUMDesa akan terpengaruh, (2). Keberlanjutan BUMDesa sangat dipengaruhi oleh skala dan jangkuan usaha. BUMDesa yang menjalankan bisnis internal (melayani kebutuhan warga setempat (seperti kebutuhan pokok, persewaan hand traktor) dengan jangkauan dan berskala lokal, umumnya menghadapi risiko yang rendah sehingga bisa berjalan sehat dan berkelanjutan. Tentu dengan catatan bahwa BUMDesa itu dikelola dengan kapasitas manajerial yang memadai dan (3). BUMDesa yang tumbuh dari solidaritas sosial dan kearifan lokal jauh lebih kuat dan berkelanjutan ketimbang BUMDesa yang lahir karena intervensi pemerintah dari atas. Hal ini disebabkan karena kearifan lokal yang paralel dengan kekayaan modal sosial dan modal politik, merupakan faktor yang sangat berpengaruh terhadap daya tahan dan keberlanjutan BUMDesa.
\end{abstract}

Kata Kunci : Kinerja Kelembagaan, BUMDESA. 


\title{
Strategy Against Institutional Development of BUMDESA in Jember Regency
}

\begin{abstract}
This study aims to determine the institutional performance of BUMDESA in Jember District. This research uses explanatory method. Data and information required consist of primary data that is data obtained from questionnaire or interview and secondary data that is supporting data obtained from related institution. The unit of analysis is Institutional BUMDesa in Jember District. The results of this study indicate that (1). Institutional governance is a key determinant of business success of each type of BUMDesa. This is because each type of business BUMDesa not stand alone but has a linkage chain with other factors that greatly affect the sustainability of the business. This linkage is like a link and when this chain breaks up the effort undertaken by BUMDesa will be affected, (2). The sustainability of BUMDesa is strongly influenced by the scale and business scope. BUMDes that run internal business (serving the needs of local people (such as basic needs, tractor rental) with local reach and scale, are generally at low risk so as to be healthy and sustainable, of course that the BUMDesa is managed with sufficient managerial capacity and (3) The growing community of social solidarity and local wisdom is much stronger and more sustainable than the BUMDES that were born because of government intervention from above because local wisdom parallel with the wealth of social capital and political capital is a very influential factor durability and sustainability of BUMDesa.
\end{abstract}

\section{Keywords: Institutional Performance, BUMDesa.}

\section{PENDAHULUAN}

Percepatan pembangunan ekonomi guna menuju kemandirian atau kedaulatan (penguatan secara berkeberlanjutan) perekonomian desa adalah hal yang krusial untuk dilakukan, dan selalu mutakhir untuk dikaji lebih lanjut (Kalla, 2011). Namun ahli lain seperti Collier dan Santoso (1996), dan Hill (1996), serta Arifin (2001) berpendapat sebaliknya, yaitu upaya perbaikan apapun untuk perdesaan atau pertanian sulit tercapai bahkan mungkin tidak berhasil. Hal ini disebabkan terutama oleh kepemilikan modal (tanah atau lahan) yang sangat rendah di sektor tradisional (perdesaan atau pertanian). Dalam perspektif hubungan perdesaan dengan perkotaan, maka prinsip yang paling penting adalah dengan mendayagunakan sumber daya ekonomi desa dan mengedepankan aktivitas ekonomi secara maksimal di desa melalui peningkatan kegiatan ekonomi yang bernilai tambah. Adapun salah satu fase yang perlu dilakukan dalam membangun desa adalah melalui penguatan organisasi (lembaga) ekonomi. 
Published Desember 2017 EKONOMIKAWAN : Jurnal Ilmu Ekonomi dan Studi Pembangunan

ISSN : 1693-7600 (Print), ISSN : 2598-0157 (Online), http://jurnal.umsu.ac.id/index.php/ekawan

Lembaga ekonomi perdesaan sampai saat ini tetap menjadi bagian penting, sekaligus masih menjadi titik lemah dalam rangka upaya mewujudkan kemandirian ekonomi desa. Hal ini nampak jika mengamati eksistensi koperasi khususnya Koperasi Unit Desa (KUD) yang telah lama berkiprah dengan pasang-surutnya, namun masih tergolong sedikit prestasinya (Rahardjo, 2011). Oleh karenanya, tetap diperlukan upaya sistematis untuk mendorong kelembagaan desa dimaksud agar mampu mengelola kapasitas sumber daya ekonomi strategis di desa, sekaligus mengembangkan jaringan untuk meningkatkan daya tahan bahkan mungkin daya saing secara ekonomi.

Secara yuridis, dalam kerangka Negara Kesatuan Republik Indonesia yang berlandaskan UUD 1945 pada Bab VI mengenai Pemerintah Daerah, dan Bab XIV mengenai Perekonomian Nasional dan Kesejahteraan Sosial, serta peraturan pelaksanaannya, maka struktur pemerintahan di Indonesia dapat ditunjukan sebagaimana Gambar 1.1. Lebih lanjut, eksistensi desa terutama menyangkut kewenangannya (otonomi) di Indonesia telah beberapa kali mengalami pasang surut. Bahkan terakhir dengan UndangUndang Nomor 32 Tahun 2004 (UU 32/2004) tentang Pemerintahan Daerah, secara tegas dan jelas memuat substansi mengenai pengakuan dan penghormatan terhadap kesatuankesatuan masyarakat hukum adat bersama hak tradisionalnya. Secara lebih spesifik, melalui Peraturan Pemerintah Nomor 72 Tahun 2005 (PP 72/2005) tentang Desa, telah mengatur hak-hak dan kewenangan desa dimaksud bahkan hingga sumber pendapatan keuangannya, yang diantaranya berasal dari usaha desa, dan secara spesifik dikenal sebagai Badan Usaha Milik Desa (BUMDes).

Dalam era reformasi dan desentralisasi di Indonesia pada akhir tahun 1990-an, melalui UU 22/1999 (pasal 108) telah mendorong pembentukan atau pendirian lembaga atau badan usaha untuk mengelola sumber dayanya secara efisien, meski tidak secara tegas menyatakan badan tersebut sebagai BUMDes. Selanjutnya, UU 32/2004 (pasal 213) sudah menyinggung secara jelas dan tegas eksistensi BUMDes sebagai unsur keuangan desa, namun keberadaannya secara eksplisit menyarankan agar desa untuk mengembangkan badan usaha berdasarkan kebutuhan dan kapasitas ekonomi yang dimiliki. Sejalan dengan semangat tersebut, pasal 78 ayat (1) PP 72/2005 menyatakan bahwa "Dalam meningkatkan pendapatan masyarakat dan desa, Pemerintah Desa dapat mendirikan Badan Usaha Milik Desa sesuai dengan kebutuhan dan potensi Desa". Kata "dapat" memang bukan suatu keharusan, atau sekedar sebagai alternatif (pilihan). Idealnya keberadaan badan usaha desa menjadi salah satu fungsi pemerintahan yaitu mengelola sumber daya ekonomi untuk kemakmuran masyarakatnya. Desa membutuhkan suatu badan usaha untuk mengelola potensinya, karena ekonomi desa selama ini mengalami keterpurukan. Selain itu, pada dasarnya keberadaan desa dalam sistem pemerintahan di Indonesia adalah untuk mengatur dan melayani serta mengurus kepentingan masyarakatnya guna membantu terwujudnya kesejahteraan.

Jika dari sisi konsep (menurut UU dan PP), pembentukan BUMDes untuk segera mewujudkan kesejahteraan masyarakat desa. Namun dari sisi implementasinya masih banyak daerah dan desa yang tidak memiliki prakarsa dan motivasi untuk mengembangkan BUMDes dimaksud. Namun demikian, yang menarik dari lembaga BUMDes ini adalah tujuan pendiriannya yang mendahulukan pendapatan (kesejahteraan) masyarakat dibandingkan dari sekedar pendapatan pemerintah desa (APBDes). 
Published Desember 2017 EKONOMIKAWAN : Jurnal Ilmu Ekonomi dan Studi Pembangunan

ISSN : 1693-7600 (Print), ISSN : 2598-0157 (Online), http://jurnal.umsu.ac.Id/index.php/ekawan

Hal ini berbeda, jika dianalogikan dengan keberadaan BUMN (atau BUMD) sebagai kekuatan yang sangat besar bagi pengembangan ekonomi Indonesia mendatang, yang keduanya mengutamakan untuk memupuk laba dan sekaligus kontributor terhadap APBN atau APBD. Dengan demikian, BUMN dan BUMD lebih cenderung sebagai entitas bisnis yang semi publik, sedangkan BUMDes memiliki keunikan sebagai usaha desa yang dikelola oleh pemerintah dan masyarakat setempat (lokal). Namun demikian, nampaknya bahwa kemandirian dan kinerja perekonomian desa (termasuk kelembagaan BUMDes) tidak hanya didasarkan pada traditional theories yang bertumpu pada keuntungan alokatif dari desentralisasi. Tetapi, kinerja ekonomi lokal sangat ditentukan oleh perilaku atau tata kelolanya sendiri yang menjadi perhatian dari new perspective theories.

Lebih dalam lagi, bahwa aktivitas menuju kemandirian ekonomi desa yang dilakukan melalui BUMDesa merupakan upaya mencapai kesejahteraan, juga sangat dipengaruhi oleh potensi dan kapasitas ekonomi sebagai bagian dari bahasan ilmu ekonomi (konvensional), serta selama ini masih banyak diacu termasuk dalam mendesain serta mengelola ekonomi perdesaan.

Kompleksnya keterkaitan pembangunan perdesaan dalam rangka meningkatkan kesejahteraan atau kemakmuran, kemandirian, dan keberlanjutan desa, maka penelitian ini lebih ditekankan pada kapasitas ekonomi desa sebagai kekuatan perekonomian desa melalui sentuhan Badan Usaha Milik Desa (BUMDesa). Pemilihan kelembagaan BUMDesa berdasarkan pertimbangan; Pertama, bahwa BUMDes merupakan organisasi atau lembaga yang relatif sangat baru, serta dianggap sebagai simplifikasi dari BUMN atau BUMD yang keberadaan dan pengelolaannya masih mengalami perdebatan yang cukup tajam. Padahal, desa dan BUMDes memiliki kelembagaan yang unik secara ekonomi, politik, dan sosial. Kedua, konsepsi pembentukan BUMDesa adalah untuk meningkatkan pendapatan masyarakat dan desa sesuai kebutuhan dan potensinya. Selanjutnya, rumusan permasalahan pada penelitian ini secara spesifik sebagai berikut : Bagaimana kondisi eksisting dan kinerja BUMDesa sebagai pelaku atau lembaga ekonomi di perdesaan di Kabupaten Jember?

\section{METODE}

Metode penelitian ini, peneliti akan menggali permasalahan yang berkaitan dengan peningkatan kinerja BUMDesa di Kabupaten Jember. Langkah pertama yang perlu dilakukan adalah mengumpulkan semua dokumen yang berkaitan dengan kegiatan BUMDesa di Kabupaten Jember. Selanjutnya mengidentifikasi permasalahan mulai dari gejala sampai masalah yang mendasar. Setelah proses identifikasi selanjutnya peneliti akan mengklasifikasikan masalah dan merumuskan strategi yang tepat yang diarahkan pada formulasi perencanaan kebijakana Penjelasan selanjutnya mengenai alat analisis dapat dijelaskan sebagai berikut.

Analisis deskriptif merupakan sebuah metode untuk menggambarkan atau menguraikan berbagai fenomena maupun informasi yang ada lalu dianalisis secara mendalam. Sedangkan metode penentuan akar masalah merupakan suatu metode analisis yang digunakan untuk mengidentifikasi permasalahan yang timbul dan mencari faktor penyebab munculnya permasalahan utama (Wicaksono \& Sugiarto, 2001:VII-2). Pemecahan suatu masalah dapat dilakukan dengan beberapa alternatif pemecahan masalah. 
Dalam upaya merumuskan dan menyusun strategi kebijakan dalam mendorong kinerja BUMDesa di Kabupaten Jember, akan digunakan model perumusan strategi yang dikembangkan oleh F.R. David. Seperti yang dikemukakan Umar (2008:31). Menurut teori manajemen strategis, strategi dapat diklasifikasikan berdasarkan tingkatan tugas. Strategi-strategi tersebut adalah strategi generik (generic strategy) yang akan dijabarkan menjadi strategi utama/induk (grand strategy). Strategi induk ini selanjutnya dijabarkan menjadi strategi tingkat fungsional, yang sering disebut dengan strategi fungsional.

Masih menurut Umar (2008:32), dalam menganalisis strategi organisasi, perlu diketahui bahwa bentuk strategi akan berbeda-beda antar-industri, antar-organisasi, dan antar-situasi. Terdapat beberapa model perumusan strategi generik dan strategi utama, yaitu model Wheelen dan Hunger, model Michael P. Porter, dan model F.R. David. Kegiatan ini akan menggunakan model F.R. David. Berdasarkan model ini penentuan strategi utama dilakukan melalui tiga tahapan (three-stage) kerangka kerja dengan matriks sebagai model analisisnya. Tahapan dalam model F.R. David ang akan digunakan dalam kegiatan ini dapat digambarkan .

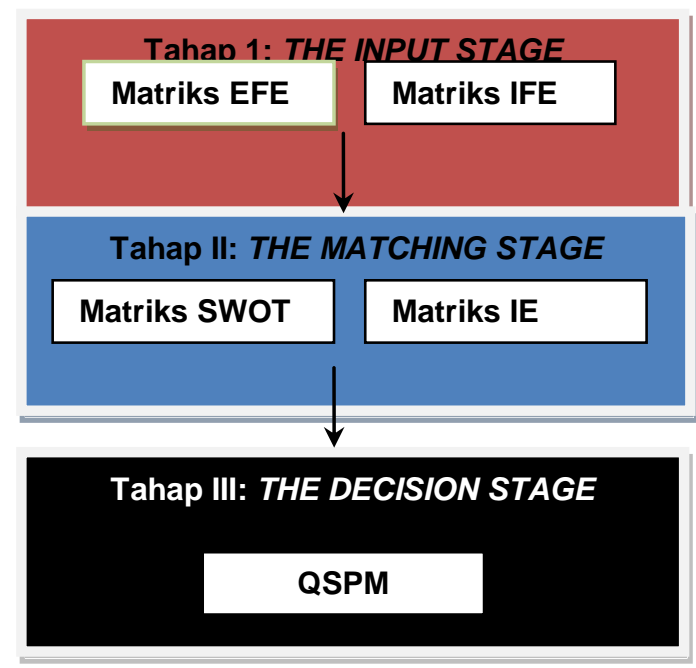

Gambar 1

Sumber: Umar (2008)

Tahapan dalam model F.R. David

\section{PEMBAHASAN}

Peningkatan kesejahteraan ekonomi masyarakat di perdesaan sudah lama dilakukan baik oleh pemerintah pusat, pemerintah propinsi maupun pemerintah daerah melalui berbagai program. Akan tetapi tujuan dari pelaksanaan program itu belum mencapai tujuan yang ditetapkan. Berbagai program pemerintah untuk pengembangan ekonomi di perdesaan antara lain Usaha Ekonomi Desa-Simpan Pinjam (UED-SP), Lembaga Simpan Pinjam Berbasis Masyarakat (LSPBM), Badan Kredit Desa (BKD), Program Penanggulangan Kemiskinan Perkotaan (P2KP), serta Program UPK-PKP-PKK sudah digulirkan untuk memperkuat perekonomian di desa, namun hasilnya belum memuaskan. 
Faktor penyebab tidak berhasilnya program-program tersebut adalah kurangnya daya kreativitas dan inovasi masyarakat desa dalam mengelola aktifitas ekonomi di perdesaan. Sistem dan mekanisme kelembagaan ekonomi di pedesaan tidak berjalan efektif sehingga berimplikasi pada kegagalan dari program yang sudah dilaksanakan.

Strategi penguatan ekonomi desa melalui BUMDesa merupakan salah satu solusi untuk melepaskan ketergantungan masyarakat desa terhadap bantuan pemerintah. Kelembagaan BUMDesa merupakan sebuah lembaga usaha yang dikelola oleh masyarakat dan pemerintahan desa serta tidak lagi didirikan atas instruksi pemerintah selain itu juga tidak dikuasai oleh kelompok tertentu serta dalam menjalankan usahanya untuk kepentingan hajat hidup orang banyak yang strategis di desa. Badan Usaha Milik Desa sebagai sebuah lembaga usaha desa yang dikelola oleh masyarakat dan pemerintahan desa dibentuk berdasarkan kebutuhan dan potensi desa yang selanjutnya disingkat dengan BUMDesa. Kelembagaan BUMDesa diharapkan sebagai alternatif kelembagaan desa yang muncul sebagai instrumen kekuatan ekonomi baru di wilayah perdesaan.

Keberadaan dari UU No 6 tahun 2014 tentang Desa memberikan payung hukum atas BUMDesa sebagai pelaku ekonomi yang mengelola potensi desa secara kolektif untuk meningkatkan kesejahteraan warga desa. Secara substansial, UU No 6 tahun 2014 mendorong desa sebagai subjek pembangunan secara emansipatoris untuk pemenuhan pelayanan dasar kepada warga, termasuk menggerakan aset-aset ekonomi lokal. Posisi BUMDesa menjadi sebagai sebuah lembaga yang dapat menumbuhkan sentra-sentra ekonomi potensial di desa dengan semangat ekonomi kolektif.

BUMDesa ini adalah suatu lembaga ekonomi yang bertujuan kepada peningkatan kesejahteraan masyarakat desa. Artinya BUMDesa sebagai salah satu pilar pembangunan desa yang diharapkan dapat mewujudkan desa mandiri yang percaya diri serta berhasil mengatur rumah tangganya sendiri sehingga desa tidak hanya bergantung kepada anggaran dana desa yang telah diberikan oleh pemerintah pusat.

\section{Karakteristik BUMDesa di Kabupaten Jember}

Makna dalam regulasi tentang pemerintahan desa secara implisit menegaskan bahwa dalam pelaksanaan pembangunan desa haruslah ditunjang dengan pendapatan desa. Oleh karena itu, desa memerlukan Badan Usaha Milik Desa (BUMDesa) agar desa nantinya mampu meningkatkan pendapatan desa. Di wilayah Kabupaten Jemberyang terdiri dari 23 kecamatan dimana setiap desa masing-masing telah mempunyai satu BUMDesa. Apabila dijumlah maka di Kabupaten Jembertelah berdiri sejumlah72 BUMDesa.

Hasil penelitian menjelaskan bahwa proses pendirian kelembagaan BUMDesa tersebut masuk dalam tipologi rekognisi yaitu proses pendirian merupakan kombinasi antara inisiatif dari atas (pemerintah) dan inisiatif dari dalam (masyarakat). Rekognisi adalah pengakuan pemerintah terhadap entitas desa. Jika pemerintah hendak memperkuat desa, maka tidak perlu membentuk lembaga-lembaga baru, melainkan mengakui, mendukung dan memperkuat aset dan institusi yang sudah ada. Implikasinya tipologi ini membutuhkan tata kelola kelembagaan yang baik serta sumber daya manusia yang mengelolanya harus berkualitas sehingga mampu membawa BUMDesa sebagai lembaga ekonomi yang dapat menggerakan potensi ekonomi masyarakat. Dua asumi dasar inilah yang harus ada apabila menghendaki BUMDesa sebagai instrumen ekonomi penggerak kemakmuran. 
Published Desember 2017 EKONOMIKAWAN : Jurnal Ilmu Ekonomi dan Studi Pembangunan

ISSN : 1693-7600 (Print), ISSN : 2598-0157 (Online), http://jurnal.umsu.ac.id/index.php/ekawan

Kelembagaan BUMDesa di Kabupeten Jember yang telah berdiri dengan jumlah 72 BUMDesa. Jumlah yang cukup besar apabila dibandingkan dengan luas wilayah kabupaten. Karakteristik dari semua BUMDesa menunjukan adanya kesamaan. Kesamaan karakteristik kelembagaan BUMDesa yang telah berdiri di Kabupaten Jember, diataranya yaitu :

1. Tahun pendirian hampir sama yaitu antara tahun 2009-2012 dan yang paling dominan pendirian BUMDesa adalah tahun 2011.

2. Legalitas kelembagaan BUMDesa adalah Perdes dan SK

3. Modal awal dari BUMDesa adalah antara RP 10.000.000-Rp 20.000.000,- dan tidak ada peningkatan asset usaha.

4. Kepemilikan dari kelembagaan BUMDesa adalah milik desa tidak adanya hak milik dari masyarakat.

5. Klasifikasi usaha yang dilakukan oleh BUMDesa adalah serving dan renting.

Fakta empiris yang menjelaskan bahwa klasifikasi usaha dari BUMDesa di Kabupaten Jember yang terdiri dari serving dan renting menjadi penguat bahwa belum terdapat asumsi dasar yang menjadi penguat bagi sebuah kelembagaan BUMDesa yaitu : tata kelola kelembagaan yang baik serta sumber daya manusia pengelolanya. Secara teoritis dan empiris terdapat 6 klasifikasi usaha yiatu : (1). serving, (2).renting, (3). banking, (4). brokering, (5). trading dan (6). holding. Klasifikasi usaha tersebut menjelaskan jenjang kualitas kelembagaan sebuah BUMDesa. Artinya sebuah BUMDesa yang mengelola usaha pada level Trading akan lebih baik tata kelola dan SDM dari pada BUMDesa yang mengelola jenis usaha serving.

Karakteristik dari kelembagaan BUMDesa di Kabupaten Jemberyang lebih berorientasi dengan jenis usaha serving dan renting. Serving bertujuan melayani warga, yakni dapat melakukan pelayanan publik kepada masyarakat. Secara substansi menjelaskan bahwa BUMDesa ini memberikan social benefits kepada warga, meskipun tidak memperoleh economic profit yang besar. Contohnya adalah jual pupuk, saprodi pertanian. Adapun jenis usaha renting bertujuan bahwa BUMDes menjalankan bisnis penyewaan untuk melayani kebutuhan masyarakat setempat dan sekaligus untuk memperoleh pendapatan desa. Contohnya adalah menyewakan terop hajatan, mesin traktor, mesin dores, menyewakan sound sistem.

Penetapan kedua jenis usaha tersebut akan menjadikan BUMDesa akan stagnan dalam jangka panjangnya sehingga sebagai sebuah lembaga ekonomi perdesaan yang mempunyai tujuan untuk mensejahterakan masyarakat akan mengalami kegagalan. BUMDesa harus lebih berani bergerak maju untuk mengelola potensi ekonomi yang terdapat didesa sebagai basis ekonominya serta berbasis pada kearifan lokal yang ada. Hal ini disebabkan apabila sebuah BUMDesa yang tumbuh dari emansipasi lokal jauh lebih kuat dan berkelanjutan ketimbang BUMDesa yang lahir karena intervensi pemerintah dari atas. Pada konteks kehidupan sebuah desa akan paralel dengan kekayaan modal sosial dan modal politik, yang merupakan faktor yang sangat berpengaruh terhadap daya tahan dan keberlanjutan BUMDesa. Jika ada bermasyarakat dan bernegara tentu juga ada berdesa. Tradisi berdesa bukan sekadar mengandung tradisi bernegara secara korporatis (tunduk pada kebijakan dan regulasi negara) atau bermasyarakat secara parokhial (hidup bersama atau tolong menolong berdasarkan garis kekerabatan, agama, etnis atau yang lain). Tradisi berdesa mengandung unsur bermasyarakat dan bernegara. Desa menjadi wadah kolektif dalam bernegara dan bermasyarakat. 
Published Desember 2017 EKONOMIKAWAN : Jurnal Ilmu Ekonomi dan Studi Pembangunan ISSN : 1693-7600 (Print), ISSN : 2598-0157 (Online), http://jurnal.umsu.ac.id/index.php/ekawan

\section{Kinerja Kelembagaan BUMDesa di Kabupaten Jember}

BUMDesa merupakan pilar kegiatan ekonomi di perdesaan yang berfungsi sebagai lembaga sosial (sosial institution) dan komersial (commmercial institutions). Oleh karena itu dalam menjalankan usahanya prinsip efisiensi dan efektifitas harus selalu ditekankan. Dengan demikian diharapkan keberadaan BUMDesa mampu mendorong dinamisasi kehidupan ekonomi di perdesaan.

Berdasarkan informasi dari beberapa informan bahwa layanan BUMDesa di Kabupaten Jember belum dapat dilaksanakan dengan profesional. Hal ini dapat mempengaruhi kelembagaan BUMDesa pada masa depannya. Sehingga tidak dapat menyerap tenaga kerja lebih besar, tidak dapat memicu pertumbuhan sektor informal lainnya serta tidak dapat mendorong kreatifitas jiwa kewirausahaan masyarakat desa dalam berkarya.

Pada pengelolaan BUMDesa yang baik, undang-undang dan peraturan pemerintah menjadi acuan untuk menjaga keberlangsungan dan kinerja BUMDesa agar tetap maksimal. Kepatuhan pengurus BUMDesa terhadap peraturan dan perundang-undangan yang berlaku merupakan salah satu aspek tinjauan kinerja suatu BUMDesa karena dengan pengelolaan yang sesuai prosedur akan didapat hasil maksimal yang dapat menguntungkan untuk BUMDesa, tapi disisi lain masyarakat juga terbantu dan pada akhirnya masyarakat mengalami peningkatan kesejahteraan dan pendapatan dari pengembangan perekonomiannya yang didukung oleh BUMDesa di desa tersebut

Kinerja BUMDesa yang baik dapat dianalisis dari beberapa parameter, diantaranya yaitu : kualitas layanan yang diberikan pada masyarakat desa, keuntungan usaha, dan keberlangsungannya. Pelayanan yang baik akan memicu masyarakat untuk ikut berpartisipasi pada BUMDesa. Pendapatan dan keuntungan yang stabil dan terus meningkat akan menjaga keberlangsungan BUMDesa itu sendiri. Hasil identifikasi dari kinerja kelembagaan BUMDesa dengan menggunakan parameter diatas dapat dijelaskan pada tabel 1 .

Tabel 1

Tabel Kinerja kelembagaan BUMDesa di Kabupaten Jember

\begin{tabular}{|c|c|c|c|c|}
\hline \multirow[b]{2}{*}{ No } & \multirow[b]{2}{*}{ Unit Usaha } & \multicolumn{3}{|c|}{ Kategori } \\
\hline & & Berkembang & $\begin{array}{c}\text { Kurang } \\
\text { Berkembang }\end{array}$ & $\begin{array}{c}\text { Tidak } \\
\text { berkembang }\end{array}$ \\
\hline 1 & Terop hajatan & & v & \\
\hline 2 & Kolam & &  & \\
\hline 3 & Mesin traktor & & m & \\
\hline 4 & Mesin Dores & & & m \\
\hline 5 & Jual Pulsa & & & m \\
\hline 6 & Hand traktor & & is & \\
\hline 7 & Pupuk kandang & & & vs \\
\hline 8 & Sound sistem & & 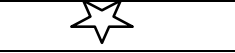 & \\
\hline
\end{tabular}


Published Desember 2017 EKONOMIKAWAN : Jurnal Ilmu Ekonomi dan Studi Pembangunan

ISSN : 1693-7600 (Print), ISSN : 2598-0157 (Online), http://jurnal.umsu.ac.id/index.php/ekawan

Tabel 1 menjelaskan bahwa jenis usaha BUMDesa yang terdapat di Kabupaten Jembersejumlah 8 jenis usaha dimana masuk dalam tipologi renting dan serving. Hasil usaha yang dilakukan oleh BUMDesa sesuai dengan data menjelaskan tidak ada satupun BUMDesa yang masuk dalam kategori berkembang. Usaha BUMDesa yang masuk kategori kurang berkembang 5 usaha, yaitu : terop hajatan, kolam, mesin traktor, hand traktor dan sound sistem. Adapun usaha yang tidak berkembang adalah jual pulsa, mesin dores, dan pupuk kandang.

Pengkategorian BUMDesa yang kurang berkembang dan tidak berkembang didasarkan pada perkembangan jumlah asset dan permodalan yang dimiliki bertambah atau kerkurang. Fakta ini menegaskan bahwa semua BUMDesa yang terdapat di Kabupaten Jembersangat membutuhkan dorongan dan untuk mengembangkan pada level berkembang. Dorongan tersebut dapat merupakan sebuah intervensi pada aspek tatakelola, SDM maupun usaha dari kelembagaan BUMDesa. Oleh karena itu Pemerintah Kabupaten Jemberseharusnya memiliki sistem perencanaan yang strategik serta fokus dalam pengembangan BUMDesa. Sistem perencanaan itu nantinya akan berkembang menjadi sebuah instrumen yang tinggal dijalankan oleh aparat pemerintah desa dan masyarakat.

\section{Format Kebijakan Peningkatan Kinerja Kelembagaan BUMDesa Di Wilayah Kabupaten Jember}

Perumusan strategi pengembangan BUMDesa dilakukan dengan menganalisis faktor internal dan eksternal BUMDesa. Analisis tersebut digunakan untuk mengetahui kekuatan, kelemahan, peluang dan ancaman yang dimiliki oleh BUMDes. Hasil analisis kemudian digunakan untuk melakukan pembobotan dan penentuan rating sehingga diketahui posisi BUMDes saat ini yaitu dalam posisi yang baik dan strategi yang dapat diterapkan adalah grow and build strategy. Alternatif strategi kemudian disusun berdasarkan posisi BUMDes saat ini dan berdasarkan analisis kekuatan, kelemahan, peluang dan ancaman melalui matriks SWOT.

\section{a. Hasil Identifikasi Kekuatan Internal BUMDesa di Kabupaten Jember}

Identifikasi terhadap faktor-faktor kekuatan internal yang berpengaruh secara langsung terhadap peningkatan kinerja kelembagaan BUMDesa yang diharapkan dapat meningkatkan perekonomian masyarakat perdesaan di wilayah Kabupaten Jember, maka selanjutnya dilakukan evaluasi terhadap faktor-faktor tersebut baik dari kekuatan dan kelemahan yang ada dengan menggunakan Matrix IFE. Berdasarkan evaluasi yang dilakukan, diperoleh hasil bobot, peringkat dan nilai pembobotan yang dapat dilihat pada Tabel 2.

Berdasarkan tabel 2 dapat diketahui bahwa terdapat empat faktor kunci kekuatan yang dimiliki untuk meningkatkan kinerja kelembagaan BUMDesa yang diharapkan dapat mendukung pengembangan ekonomi masyarakar perdesaan di Kabupaten Jember. Faktor kekuatan-kekuatan internal yang dapat diidenfitikasi, yaitu :

1. Jumlah dan kualitas SDA serta potensi ekonomi lokal

2. Potensi terhadap nilai kearifan lokal dan solidaritas sosial

3. Regulasi yang jelas dan mendukung terhadap sistem penyelenggaraan BUMDesa

4. Tingginya komitmen pemerintahan Kabupaten dan para pihak terkait dengan BUMDesa 
Published Desember 2017 EKONOMIKAWAN : Jurnal Ilmu Ekonomi dan Studi Pembangunan

ISSN : 1693-7600 (Print), ISSN : 2598-0157 (Online), http://jurnal.umsu.ac.id/index.php/ekawan

Tabel 2

Matrik Hasil Perhitungan Iternal Factor Evaluation (IFE)

\begin{tabular}{|c|c|c|c|}
\hline Faktor Strategis & Bobot & Rating & Skor \\
\hline \multicolumn{4}{|l|}{ Kekuatan } \\
\hline $\begin{array}{l}\text { a. Jumlah dan kualitas SDA serta potensi ekonomi } \\
\text { lokal }\end{array}$ & 4.126 & 4 & 0.486 \\
\hline b. Potensi terhadap nilai kearifan lokal & 0.120 & 3 & 0.154 \\
\hline $\begin{array}{l}\text { c. Regulasi yang jelas dan mendukung terhadap } \\
\text { sistem penyelenggaraan BUMDesa }\end{array}$ & 0.98 & 3 & 0.130 \\
\hline $\begin{array}{l}\text { d. Tingginya komitmen pemerintahan Kabupaten } \\
\text { dan para pihak terkait dengan BUMDesa }\end{array}$ & 3.188 & 3 & 0.020 \\
\hline
\end{tabular}

\section{Kelemahan}
a. Kualitas terhadap sumberdaya manusia pelaksana dari BUMDesa
b. Sistem penyelengaaraan pemerintah desa dan kelembagaan yang belum optimal menudukung.
c. Terbatasnya inovasi dan kreatifitas dari pengelola BUMDesa

$\begin{array}{lll}0.109 & 3 & 0.301\end{array}$
0.090
3
0.128
2
d. Tata kelola dan penyelnggaraan BUMDesa yang 0.109

$2 \quad 0.210$ masih terbatas
e. Terbatasnya sarana dan prasarana yang dimiliki oleh kelembagaan BUMDesa
0.134
1
0.026
Total

Dari keempat faktor internal tersebut, faktor Jumlah dan kualitas SDA serta potensi ekonomi lokal merupakan faktor kunci kekuatan dari dalam untuk meningkatkan kinerja kelembagaan BUMDesa di Kabupaten Jemberyang memiliki nilai skor tertinggi sebesar 0,486 dengan rating bernilai 4. Hal ini menunjukkan bahwa Jumlah dan kualitas SDA serta potensi ekonomi lokal merupakan faktor kekuatan yang paling berpengaruh dalam mendukung upaya peningkatan kinerja kelembagaan BUMDesa.

Faktor kekuatan yang teridentifikasi diatas menjelaskan bahwa untuk meningkatkan pendapatan masyarakat desa maka tiap-tiap wilayah perdesaan harus berupaya untuk menggali potensi-potensi sumber daya alam sebagai basis untuk pengembangan ekonomi perdesaan serta pengembangan potensi sumberdaya lokal. Bagi wilayah perdesaan yang kaya akan sumber daya ekonomi potensial akan menjadi lebih mudah dalam menciptakan produk-produk ekonomi unggulan, namun bagi wilayah-wilayah marginal, baik dari sisi keterbatasan kondisi fisik maupun sumberdaya manusia maka upaya untuk menggali potensi ekonomi unggulan merupakan satu pekerjaan yang menuntut kerja keras, kreativitas dan dukungan dari segala pihak, baik dari pemerintah, masyarakat maupun dunia usaha. 
Published Desember 2017 EKONOMIKAWAN : Jurnal Ilmu Ekonomi dan Studi Pembangunan

ISSN : 1693-7600 (Print), ISSN : 2598-0157 (Online), http://jurnal.umsu.ac.Id/index.php/ekawan

Selain kekuatan internal yang dapat mendukung peningkatan kinerja kelembagaan BUMDesa di Kabupaten Jemberternyata juga terdapat lima elemen kunci faktor-faktor kelemahan yang mempengaruhi kinerja kelembagaan BUMDes yang sudah dapat diidentifikasi, yaitu :

1. Kualitas terhadap sumberdaya manusia pelaksana dari BUMDesa

2. Sistem penyelengaaraan pemerintah desa dan kelembagaan yang belum optimal menudukung

3. Terbatasnya inovasi dan kreatifitas dari pengelola BUMDesa

4. Tata kelola dan penyelnggaraan BUMDesa yang masih terbatas

5. Terbatasnya sarana dan prasarana yang dimiliki oleh kelembagaan BUMDesa

Dari kelima faktor internal tersebut, bahwa faktor Kualitas terhadap sumberdaya manusia pelaksana dari BUMDesa merupakan kelemahan utama yang mempunyai pengaruh paling besar terhadap peningkatan kinerja kelembagaan BUMDesa. Hal ini ditunjukkan dengan nilai skor yang diperoleh dari matriks IFE sebesar 0,301 dengan nilai rating 1. Sesuai dengan yang disampaikan oleh hasil penelitian tim PKDSP-UB (2009) menjelaskan bahwa lemahnya sumberdaya manusia pengelola kelembagaan BUMDesa akan berdampak buruk pada keberlanjutan serta pengembangan BUMDesa. Kualitas SDM yang lemah dan terbatas akan sulit bagi BUMDesa untuk melakukan pengembangan usaha. Dengan demikian dibutuhkan adanya sumberdaya manusia yang dapat mendukung baik dari sisi manajerial kelembagaan dan manajemen usaha/bisnis.

\section{b. Hasil Identifikasi Kekuatan Eksternal BUMDesa di Kabupaten Jember}

Identifikasi yang dilakukan terhadap lingkungan eksternal terkait dengan kinerja kelembagaan BUMDesa di Kabupaten Jember, menunjukkan adanya beberapa faktor berpengaruh yang terdiri dari peluang dan ancaman. Faktor-faktor tersebut kemudian dievalusi menggunakan Matrix External Factor Evaluation (EFE). Dengan melakukan evaluasi terhadap faktor-faktor tersebut, dapat ditentukan strategi yang tepat dalam melakukan peningkatan kinerja kelembagaan BUMDes. Hasil Perhitungan EFE dapat dilihat pada tabel 3.

Berdasarkan hasil identifikasi factor-faktor eksternal, diketahui bahwa terdapat lima faktor strategis peluang yang mempengaruhi peningkatan kinerja BUMDesa yang terdapat di Kabupaten Jember, yaitu :

1. Potensi pasar yang luas dan dinamis

2. Berkembangnya sektor pariwisata daerah

3. Perkembangan teknologi informasi

4. Budaya penduduk setempat atau solidaritas sosial

5. Dukungan pihak swasta dan perguruan tinggi

Dari lima faktor strategis peluang tersebut, menjelaskan bahwa faktor potensi pasar yang luas dan dinamis merupakan faktor eksternal yang memiliki nilai skor paling tinggi sebesar 0,529 dengan rating 4. Hal ini menunjukkan bahwa potensi pasar yang luas dan dinamis merupakan faktor peluang yang sangat berpengaruh dan dapat dimanfaatkan dengan sangat baik oleh kelembagaan BUMDesa. Potensi pasar yang luas dan dinamis merupakan endoment factor potensial yang dimiliki oleh setiap BUMDesa di Kabupten Lumajang. 
Published Desember 2017 EKONOMIKAWAN : Jurnal Ilmu Ekonomi dan Studi Pembangunan

ISSN : 1693-7600 (Print), ISSN : 2598-0157 (Online), http://jurnal.umsu.ac.id/index.php/ekawan

Tabel 3

Matrik Hasil Perhitungan Eksternal Factor Evaluation (EFE)

Faktor Strategis

Peluang

a. Potensi pasar yang luas dan dinamis

b. Berkembangnya sektor pariwisata daerah

c. Perkembangan teknologi informasi

d. Budaya penduduk setempat atau solidaritas sosial

e. Dukungan pihak swasta dan perguruan tinggi

Ancaman

a. Sertifikasi dan fluktuasi harga produk usaha kecil

b. Persaingan dengan lembaga ekonomi lainnya

c. Skala usaha yang masih kecil dan terbatas

d. Mengurangi minat usaha bagi masyarakat desa

Total

Bobot Rating Skor

$\begin{array}{ccc}4.137 & 4 & 0.529 \\ 4.120 & 4 & 0.200 \\ 0.118 & 3 & 0.347 \\ 0.103 & 3 & 0.113 \\ 2.110 & 2 & 0.020\end{array}$

$\begin{array}{lll}0.110 & 3 & 0.337 \\ 4.71 & 4 & 0.177 \\ 2.111 & 2 & 0.143 \\ 0.120 & 1 & 0.120\end{array}$

$\begin{array}{lll}0.110 & 3 & 0.337\end{array}$

$2.111 \quad 2 \quad 0.143$

1

1.980

Dengan memanfaatkan adanya peluang potensi pasar yang luas dan dinamis akan mampu bertahan dalam persaingan bisnis serta mendorong tumbuhnya usaha ekonomi rakyat kecil lainnya. Potensi pasar yang luas dan besar yang dimiliki oleh kelembagaan BUMDesa merupakan peluang sekaligus tantangan untuk dapat melakukan pengelolaan yang baik terhadap tata kelola kelembagaan BUMDesa pada masa depan. Dengan dukungan sarana dan prasarana yang ada serta kualitas SDM pengelola BUMDesa maka secara optimis peran dan fungsi dari kelembagaan BUMDesa akan dapat menjawab tantangannya yaitu mewujudkan kesejahteraan masyarakat desa.

Selain faktor peluang terdapat faktor strategis yang merupakan ancaman. Hasil identifikasi menjelaskan terdapat empat faktor ancaman yang dirasa akan menghambat proses peningkatan kinerja kelembagaan BUMDesa di Kabupaten Jember, diantaranya yaitu :

1. Sertifikasi dan fluktuasi harga produk usaha kecil

2. Persaingan dengan lembaga ekonomi lainnya

3. Skala usaha yang masih kecil dan terbatas

4. Mengurangi minat usaha bagi masyarakat desa

Dari keempat faktor ancaman tersebut dapat dijelaskan bahwa faktor sertifikasi dan fluktuasi harga produk usaha kecil merupakan faktor ancaman yang dirasa sangat berpengaruh pada peningkatan kinerja kelembagaan BUMDesa. Hal ini sesuai dengan nilai skor pada matriks EFE sebesar 0,337. Sertfikasi merupakan standart kualitas terhadap semua produk dan jasa yang akan dipasarkan secara luas. Adanya sertifikasi ini mengharuskan pengelola BUMDesa untuk menghasilkan suatu produk dan jasa yang sesuai dengan pasar sehinga membutuhkan proses produksi dan penggunaan teknologi yang tepat. Hal ini diharapkan pada masa depan akan menunjukan bahwa produk dan jasa yang dihasilkan kelembagaan BUMDesa sesuai dengan standart ketentuan yang ditetapkan oleh lembaga sertifikasi. 
Published Desember 2017

\section{c. Alternatif Strategi Peningkatan Kinerja Kelembagaan BUMDesa}

Hasil analisis data dengan perhitungan matrix IFE dan EFE, didapatkan fomulasi strategi yang tepat untuk meningkatkan kinerja kelembagaan BUMDesa di Kabupaten Jemberadalah Strategi Optimalisasi Tata Kelola Kelembagaan BUMDesa dan Strategi Pengembangan usaha dengan berbasiskan pada potensi ekonomi serta kearifan lokal. Hal ini didasari oleh hasil pemetaan total matriks IFE dan total matriks EFE pada matriks IE. Hasil analisis data juga menjelaskan bahwa kelembagaan BUMDesa saat ini berada pada sel IX (Gambar 1).

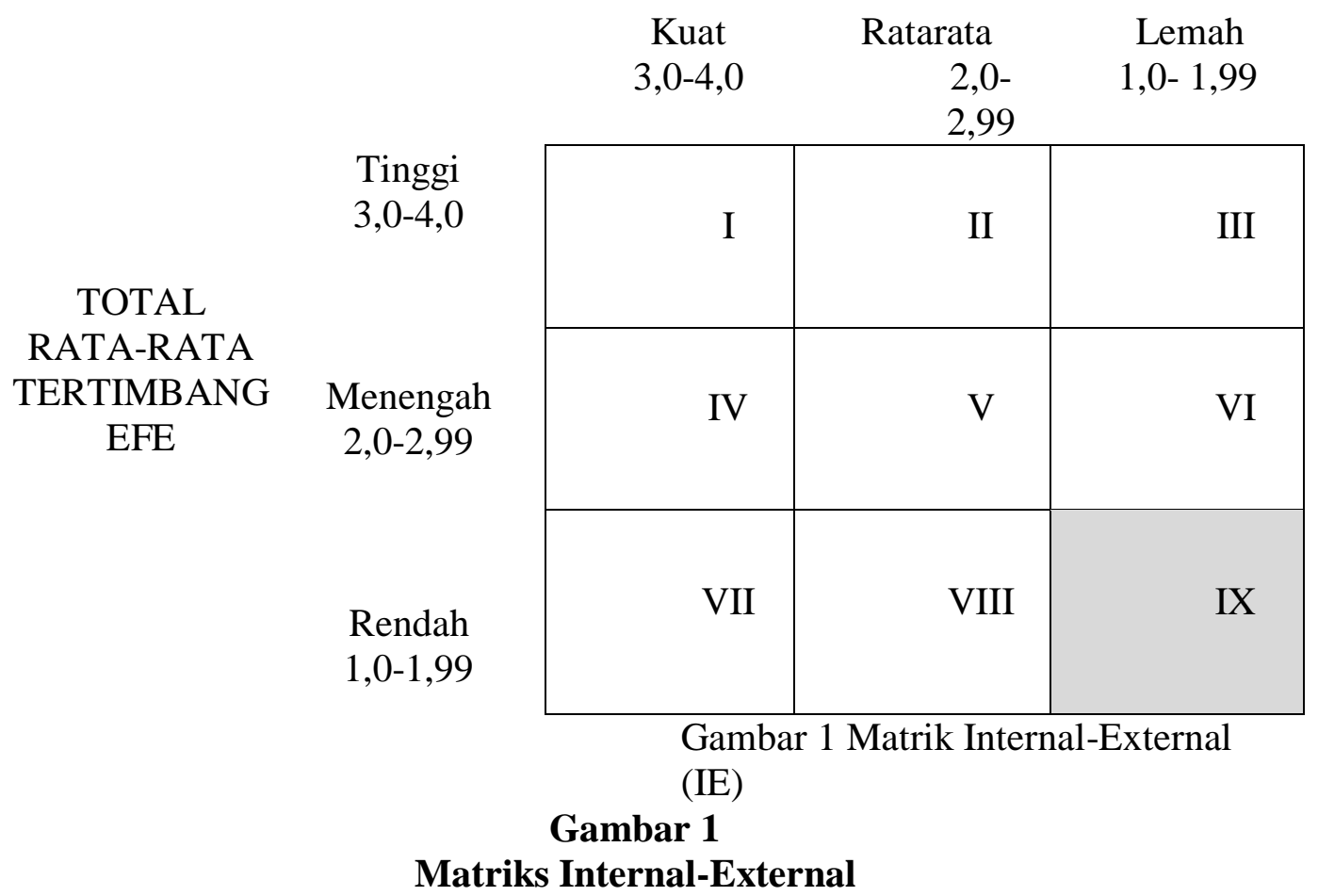

Dengan mengacu pada kedua jenis strategi tersebut, maka dilakukan pengembangan strategi menggunakan analisis SWOT dan diperoleh sembilan alternatif strategi yang dapat digunakan dalam peningkatan kinerja kelambagaan BUMDesa. Alternatif strategi tersebt dapat dilihat pada tabel 4 . 
Tabel 4

Alternatif strategi yang dapat digunakan dalam peningkatan kinerja kelambagaan BUMDesa

\begin{tabular}{|c|c|c|}
\hline EFE & $\begin{array}{l}\quad \text { Kekuatan } \\
\qquad \text { (Strengths/S) } \\
\text { 1. Jumlah dan kualitas SDA sert } \\
\text { potensi ekonomi lokal } \\
\text { 2. Potensi terhadap nilai kearifan } \\
\text { lokal } \\
\text { 3. Regulasi yang jelas dan } \\
\text { mendukung terhadap sistem } \\
\text { penyelenggaraan BUMDesa } \\
\text { 4. Tingginya komitmen } \\
\text { pemerintahan Kabupaten dan } \\
\text { para pihak terkait dengan } \\
\text { BUMDesa }\end{array}$ & $\begin{array}{l}\quad \text { Kelemahan } \\
\text { Weaknesess/W) } \\
\text { 1. Kualitas terhadap } \\
\text { sumberdaya manusia } \\
\text { pelaksana dari BUMDesa } \\
\text { 2. Sistem penyelengaaraan } \\
\text { pemerintah desa dan } \\
\text { kelembagaan yang belum } \\
\text { optimal menudukung } \\
\text { 3. Terbatasnya inovasi dan } \\
\text { kreatifitas dari pengelola } \\
\text { BUMDesa } \\
\text { 4. Tata kelola dan } \\
\text { penyelenggaraan BUMDesa } \\
\text { yang masih terbatas } \\
\text { 5. Terbatasnya sarana dan } \\
\text { prasarana yang dimiliki oleh } \\
\text { kelembagaan BUMDesa }\end{array}$ \\
\hline \begin{tabular}{|l|}
\multicolumn{1}{|c}{ Peluang } \\
(Opportunities/O) \\
1. Potensi pasar yang luas dan \\
dinamis
\end{tabular} & \begin{tabular}{|l|}
\multicolumn{1}{|c|}{ Strategi S-O } \\
\\
- \\
Optimalisasi kinerja BUMDes \\
dengan pengembangan SDM \\
berbasis potensi ekonomi \\
(SO1) \\
- Pembentukan usaha \\
kemitraan dengan pihak \\
swasta dan PT (SO2) \\
- Pendirian pusat pelayanan \\
informasi BUMDesa berbasis \\
T.I (SO3)
\end{tabular} & $\begin{array}{l}\text { Meningkatkan pelatihan dan magang } \\
\text { bagi pengelola untuk } \\
\text { mengoptimalkan fungsi kegiatan } \\
\text { usaha (WO1) } \\
\text { - Mendukung setiap kegiatan sosial } \\
\text { desa sebagai media sosialisasi } \\
\text { program BUMDesa (WO2) } \\
\text { - Pengajukan kebutuhan sumberdaya } \\
\text { tenaga ahli pendamping (WO3) }\end{array}$ \\
\hline $\begin{array}{l}\text { Ancaman } \\
\qquad(\text { Threats/T) } \\
\\
\text { 1. Sertifikasi dan fluktuasi } \\
\text { harga produk usaha kecil } \\
\text { 2. Persaingan dengan } \\
\text { lembaga ekonomi lainnya } \\
\text { 3. Skala usaha yang masih } \\
\text { kecil dan terbatas } \\
\text { 4. Mengurangi minat usaha } \\
\text { bagi masyarakat desa }\end{array}$ & \begin{tabular}{|l|}
\multicolumn{1}{|c|}{ Strategi S-T } \\
\\
- \\
Peningkatan kualitas teknik \\
produksi dan diversifikasi \\
usaha (ST1) \\
- Kerjasama dengan lembaga \\
pengembangan ekonomi \\
masyarakat lain yang \\
bertujuan pemberdayaan \\
ekonomi (ST2)
\end{tabular} & $\begin{array}{l}\text { - Penyediaan pusat pemasaran terpadu } \\
\text { untuk produk industri dan jasa } \\
\text { unggulan daerah khususnya di pusat } \\
\text { keramaian masyarakat }\end{array}$ \\
\hline
\end{tabular}




\section{KESIMPULAN}

Berdasarkan hasil analisis data dan pembahasan, hasil penelitian ini dapat menyimpulkan, diantaranya yaitu : (1). Tata kelola kelembagaan merupakan faktor kunci penentu keberhasilan usaha dari setiap jenis BUMDesa. Hal ini disebabkan karena setiap jenis usaha BUMDesa tidak berdiri sendiri tetapi memiliki kaitan mata rantai dengan faktor lain yang sangat mempengaruhi keberlanjutan usaha. Keterkaitan ini bagaikan sebuah mata rantai dan apabila rantai ini putus maka usaha yang dilakukan oleh BUMDesa akan terpengaruh, (2). Keberlanjutan BUMDesa sangat dipengaruhi oleh skala dan jangkuan usaha. BUMDesa yang menjalankan bisnis internal (melayani kebutuhan warga setempat (seperti kebutuhan pokok, persewaan hand traktor) dengan jangkauan dan berskala lokal, umumnya menghadapi risiko yang rendah sehingga bisa berjalan sehat dan berkelanjutan. Tentu dengan catatan bahwa BUMDesa itu dikelola dengan kapasitas manajerial yang memadai dan (3). BUMDesa yang tumbuh dari solidaritas sosial dan kearifan lokal jauh lebih kuat dan berkelanjutan ketimbang BUMDesa yang lahir karena intervensi pemerintah dari atas. Hal ini disebabkan karena kearifan lokal yang paralel dengan kekayaan modal sosial dan modal politik, merupakan faktor yang sangat berpengaruh terhadap daya tahan dan keberlanjutan BUMDesa.

Hasil penelitian ini memberikan beberapa saran terkait dengan peningkatan kinerja kelembagaan BUMDesa, diantaranya yaitu : (1). Mengacu sebagai sebuah lembaga layanan publik serta terkait standar operasional prosedur dari kelembagaan BUMDesa yang masih kurang baik, maka perlu ditingkatkan kualitas dan kuantitas pelatihanpelatihan manajemen dan administrasi untuk para pengelola atau pengurus BUMDesa, (2). Mengacu pada aspek kinerja yang masih rendah minat, kemampuan dan kesadaran pengelola BUMDesa untuk berfokus pada usaha sektor riil dan tidak hanya berfokus pada sektor simpan pinjam maka perlu diberikan sosialisasi pentingnya kemandirian berwirausaha pada masyarakat dan konsultasi mengenai potensi bisnis, dan (3). Melakukan sistem pembagian kerja yang lebih spesifik dalam pengelolaan BUMDesa sehingga BUMDesa dapat lebih berkembang dan berkelanjutan.

\section{DAFTAR PUSTAKA}

Abdul-Hakim, R., Abdul-Razak, N.A., Ismail, R. 2010. Does Social Capital Reduce Poverty? A Case Study of Rural Households in Terengganu, Malaysia. European Journal of Social Sciences, Vol. 14, No. 4: 556-566.

Adjargo, G. 2012. Social Capital: An Indispensable Resource in Ghana. Journal of Sustainable Development in Africa, Vol. 14, No. 3: 219-227.

Arifin, B. 2001. Spektrum Kebijakan Pertanian Indonesia: Telaah Struktur, Kasus, dan Alternatif Strategi, Erlangga. Jakarta.

Asshiddiqie, J. 2010. Konstitusi Ekonomi, Kompas Media Nusantara. Jakarta.

Baswir, R. 2009. Bahaya Neoliberalisme, Pustaka Pelajar. Yogyakarta.

Boeke, J.H. 1971. Batas-batas dari Masyarakat Pedesaan di Indonesia, LP3ES. Jakarta. 
1983. Prakapitalisme di Asia, Sinar Harapan. Jakarta.

Budiman, A. 1995. Teori Pembangunan Dunia Ketiga, Gramedia Pustaka Utama. Jakarta.

Bungin, H.M.B. 2008. Penelitian Kualitatif: Komunikasi, Ekonomi, Kebijakan Publik, dan Ilmu Sosial Lainnya, Kencana (Prenada Media Group). Jakarta.

Caporaso, J.A., Levine, D.P. 2008. Theories of Political Economy. Suraji (penerjemah). Teori-Teori Ekonomi Politik, Pustaka Pelajar. Yogyakarta.

Carroll, M.C., Stanfield, J.R. 2003. Social Capital, Karl Polanyi, and American Social and Institutional Economics. Journal of Economic Issues. Vol. XXXVII, No. 2 June: 397-404.

Coleman, J.S. 2010. Foundations of Social Theory. Imam Muttaqien dkk. (penerjemah). Dasar-Dasar Teori Sosial, Nusa Media. Bandung.

Collier, P. 2010. The Political Economy of Natural Resources. Social Research. Vol. 77, No. 4 Winter: $1105-1132$.

Collier, W.L., Santoso, K. 1996. A New Approach to Rural Development in Java: Twenty Five Years of Village Studies. Sajogyo (penerjemah). Pendekatan Baru Dalam Pembangunan Pedesaan di Jawa: Kajian Pedesaan Selama Dua Puluh Lima Tahun, Yayasan Obor Indonesia. Jakarta.

Connell, D.J., Wall, E. 2004. New Rural Economy: Economic Capacity Profile. Journal of Extension. Volume : 42, Number : 4, http://www.joe.org/joe/2004august/a2.php. Agust 2011.

Creswell, J.W. 2010. Research Design: Qualitative, Quantitative, and Mixed Methods Approaches. Achmad Fawaid (penerjemah). Research Design: Pendekatan Kualitatif, Kuantitatif, dan Mixed, Pustaka Pelajar. Yagyakarta.

Deliarnov. 2005. Perkembangan Pemikiran Ekonomi, RajaGrafindo Persada. Jakarta. 2006. Ekonomi Politik, Erlangga. Jakarta.

Deolalikar, et.al. 2002. Poverty Reduction and the Role of Institutions in Developing Countries. ERD Working Paper. No. 10 Asian Development Bank.

Dequech, D. 2002. The Demarcation between the "Old" and the "New" Institutional Economics: Recent Complications, Journal of Economic Issues. Vol. XXXVI, No.2 June: 565-572.

Dharmawan, A.H. 2006. Pendekatan-Pendekatan Pembangunan Pedesaan dan Pertanian: Klasik dan Kontemporer, makalah seminar "Apresiasi Perencanaan Pembangunan Pertanian Daerah bagi Tenaga Pemandu Teknologi Mendukung Prima Tani”. Cisarua Bogor. 19-25 November.

Dharmawan, B. (ed.). 2007. Esai-esai Nobel Ekonomi, Kompas Media Nusantara. Jakarta.

Dwiyanto, A. 2011. Mengembalikan Kepercayaan Publik Melalui Reformasi Birokrasi. Gramedia Pustaka Utama. Jakarta. 
Ekelund Jr., R.B., Hébert, R.F. 2007. A History of Economic Theory and Method (Fifth Edition). Waveland Press, Inc. Ilinois

Emzir. 2010. Metodologi Penelitian Kualitatif: Analisis Data, Rajawali Pers. Jakarta.

Fakultas Ekonomi dan Bisnis Universitas Brawijaya. 2011. Spirit Konstitusi, Hegemoni Modal, dan Kedaulatan Ekonomi, Refleksi Akademik 50 Tahun Fakultas Ekonomi dan Bisnis Universitas Brawijaya. 8 Oktober.

Field, J. 2005. Social Capital (Modal Sosial), Bina Media Perintis. Medan.

Franke, S. 2005. Measurement of Social Capital: Reference Document for Public Policy Research, Development, and Evaluation, Report to the Policy Research Initiative (PRI), September, Ottawa, Canada.

Fukuyama, F. 2005. The Great Disruption: Human Nature and the Reconstitution of Social Order. Masri Maris (penerjemah). Guncangan Besar: Kodrat Manusia dan Tata Sosial Baru, Gramedia Pustaka Utama. Jakarta.

Giddens, A. 2010. The Constitution of Society: Outline of the Theory of Structuration. Maufur dan Daryatno (penerjemah). Teori Strukturasi: Dasar-Dasar Pembentukan Struktur Sosial Masyarakat, Pustaka Pelajar. Yogyakarta.

Glascock, A. P., Kutzik, D. M. 2010. The Capital Use of Social Capital or How Social Capital is Used to Keep Capital Concentrated. International Journal of Social Inquiry, Vol. 3, No. 2: 101-119.

Gregg, S. 2010. Smith Versus Keynes: Economics and Political Economy in the PostCrisis Era. Harvard Journal of Law \& Public Policy, Vol. 33, No. 2 Spring: 443464.

Gregory, P., Stuart, R. 1998. Comparing Economic Systems in the Twenty-First Century, Houghton Mifflin Company. USA.

Hill, H. 1996. The Indonesian Economy Since 1966: Southeast Asia's Emerging Giant. Anggito Abimanyu (penerjemah). Transformasi Ekonomi Indonesia Sejak 1966: Sebuah Studi Kritis dan Komprehensif, Pusat Antar Universitas (Studi Ekonomi) UGM dan Tiara Wacana. Yogyakarta.

Ismail, M. 2003. Sumbangan Institusi Lokal Dalam Pembangunan Ekonomi. dalam Iwan Triyuwono dan Ahmad Erani Yustika (eds.), Emansipasi Nilai Lokal: Ekonomi dan Bisnis Pascadesentralisasi Pembangunan, Bayumedia Publishing. Malang: 122.

Malik, A. 2008. Implementasi Perimbangan Keuangan Antara Kabupaten dan Desa Melalui Alokasi Dana Desa (ADD) Dalam Menunjang Pembangunan Desa: Studi Kasus Tiga Desa di Kabupaten Jember. Disertasi, Program Pascasarjana Fakultas Ekonomi Universitas Brawijaya. Malang.

Manig, W. 1992. Structural and Institutional Changes in Rural Nortwest Pakistan. The Journal of Development Studies, Vol. XII: 1-20.

Martins, N. 2011. Sustainability Economics, Ontology and the Capability Approach. Ecological Economics, No. 72: 1-4. 
Published Desember 2017 EKONOMIKAWAN : Jurnal Ilmu Ekonomi dan Studi Pembangunan

ISSN : 1693-7600 (Print), ISSN : 2598-0157 (Online), http://jurnal.umsu.ac.id/index.php/ekawan

Maryunani (ed.). 2002. Alokasi Dana Desa: Formulasi dan Implementasi, LPEM Fakultas Ekonomi Universitas Brawijaya. Malang.

2007. Sentuhan Pembangunan Ekonomi Dalam Penguatan Perekonomian Desa di Indonesia, Pidato Pengukuhan Guru Besar dalam Bidang Ilmu Ekonomi Pembangunan, Fakultas Ekonomi Universitas Brawijaya. 22 Oktober.

Miles, M.B., Huberman, A.M. 1992. Qualitative Data Analysis. Tjetjep Rohendi Rohidi (penerjemah). Analisis Data Kualitatif: Buku Sumber Tentang Metode-metode Baru, Penerbit Universitas Indonesia (UI-Press). Jakarta.

Miller, B. 1992. Collective Action and Rational Choice: Place, Community, and the Limits to Individual Self-interest, Economic Geography, Vol. 68, No. 1, January: 22-42.

Min, H. 2011. Former Officials and Subsidies to State-Owned Enterprises, Journal of Economic Development, Vol. 36, No. 2, June: 1-13.

Muhadjir, N. 2002. Metodologi Penelitian Kualitatif, Rake Sarasin. Yogyakarta.

Munawar. 2007. Kritik Sosiologis Terhadap Kedudukan Individu Dalam Bangunan Teori Ekonomi Neoklasik, Pidato Pengukuhan Guru Besar dalam Bidang Ilmu Ekonomi Makro, Fakultas Ekonomi Universitas Brawijaya. 10 Desember.

Naghavi, M. A. S., Salavati, A., and Movahed, E. S. B. 2011. Public Sector Success in Social Capital: A Comparative Study in Iran's Governmental and Private Banks, European Journal of Social Sciences, Vol. 24, No. 1: 33-41.

Osborne, D., Gaebler, T. 1996. Reinventing Government: How the Entrepreneurial Spirit is Transforming the Public Sector. Abdul Rosyid (penerjemah). Mewirausahakan Birokrasi: Mentransformasi Semangat Wirausaha ke dalam Sektor Publik, Pustaka Binaman Pressindo. Jakarta.

Osborne, D., Plastrik, P. 2000. Banishing Bureaucracy: the Five Strategies for Reinventing Government. Abdul Rosyid dan Ramelan (penerjemah). Memangkas Birokrasi: Lima Strategi Menuju Pemerintahan Wirausaha, Penerbit PPM. Jakarta.

Peukert, H. 2001. Bridging Old and New Institutional Economics: Gustav Schmoller and Douglass C. Nort, Seen with Oldinstitutionalists' Eyes. European Journal of Law and Economics. Vol.11, No.2: 91-130.

Prasad, B.C. 2003. Institutional Economics and Economic Development: The Theory of Property Rights, Economic Development, Good Governance and the Environment. International Journal of Social Economics. Vol. 30, No. 6: 741762.

Ritzer, G., Smart, B. (eds.). 2012. Handbook of Social Theory. Imam Muttaqien dkk. (penerjemah). Handbook Teori Sosial, Nusa Media. Bandung.

Rutherford, M. 2001. Institutional Economics: Then and Now. Journal of Economic Perspectives. Vol.15, No. 3 Summer: 173-194.

Samuels, W.J. 2000. Institutional Economics after One Century. Journal of Economic Issues. Vol. XXXIV, No.2 June: 305-315. 
Sen, A. 2007. Identity and Violence: The Illusion of Destiny. Arif Susanto (penerjemah). Kekerasan dan Ilusi tentang Identitas, Marjin Kiri. Serpong-Tangerang.

Skousen, M. 2006. The Making of Modern Economics: The Lives and Ideas of Great Thinkers. Tri Wibowo Budi Santoso (penerjemah). Sang Maestro Teori-teori Ekonomi Modern: Sejarah Pemikiran Ekonomi, Prenada Media. Jakarta.

Smelser, J. 1987. The Sosiology of Economic Life. Hisymi Ali (penerjemah). Sosiologi Ekonomi, Bahana Aksa. Jakarta.

Sobel, J. 2002. Can We Trust Social Capital?. Journal of Economic Literature. Vol. XL March: 139-154.

Srinivasan, T.N. 2000. The Washington Consensus a Decade Later: Ideology and the Art and Science of Policy Advice.The World Bank Research Observer, Vol. 15, No. 2: $265-270$.

Stiglitz, J.E. 2003. The Roaring Nineties: A New History of the World's Most Prosperous Decade. Aan Suhaeni (penerjemah). Dekade Keserakahan: Era '90-an dan Awal Mula Petaka Ekonomi Dunia, Marjin Kiri. Serpong-Tangerang.

Vel, J. 2010. The Uma-Economy: Indigenous economics and development work in Lawonda, Sumba (Eastern-Indonesia). Myrne Tehubijuluw-Umboh (penerjemah). Ekonomi-Uma: Penerapan adat dalam dinamika ekonomi berbasis kekerabatan, HuMa; Van Vollenhoven Institute; KITLV. Jakarta.

Wallis, J., Kilerby, P., Dollery, B. 2004. Social Economics and Social Capital. International Journal of Social Economics. Vol. 31 No. 3: 239-258.

Yustika, A.E. 2003. Industrialisasi, Urbanisasi, dan Sektor Informal: Perspektif Kebijakan Lokal. dalam Iwan Triyuwono dan Ahmad Erani Yustika (eds.), Emansipasi Nilai Lokal: Ekonomi dan Bisnis Pascadesentralisasi Pembangunan, Bayumedia Publishing. Malang: 33-50.

2008. Ekonomi Kelembagaan: Definisi, Teori, dan Strategi, Bayumedia Publishing. Malang.

. 2009. Ekonomi Politik: Kajian Teoretis dan Analisis Empiris, Pustaka Pelajar. Yogyakarta.

Zhang, S., Anderson, S.G., Zhan, M. 2011. The Differentiated Impact of Bridging and Bonding Social Capital on Economic Well-Being: An Individual Level Perspective, Journal of Sociology \& Social Welfare, Vol. XXXVIII, No. 1 Maret: 119-142. 